\title{
Diagnosis and Management of Atopic Dermatitis for Primary Care Providers
}

\author{
Patrick Fleming, MD, MSc, FRCPC, , Yue Bo Yang, BSc, ${ }^{*}$ Charles Lynde, MD, FRCPC, \\ Braden O'Neill, MD, DPhil, CCFP, and Kyle O. Lee, BM, BS, CCFP
}

Objective: To provide primary care providers an up-to-date approach to the diagnosis and management of atopic dermatitis (AD).

Quality of Evidence: PubMed, Cochrane, and MEDLINE databases were searched for relevant metaanalyses, randomized controlled trials, systematic reviews, and observational studies about the diagnosis and management of AD.

Main Message: AD is a common chronic skin disease characterized by immune dysregulation and skin barrier dysfunction. It has a substantial impact on quality of life across all ages. Despite this, AD is often still undertreated due to inaccurate diagnoses, even by many experienced dermatologists. Many primary care providers may not be aware of its commonly associated medical and psychiatric comorbidities or be familiar with new treatment options.

Conclusion: In this clinical review, we describe the pathophysiology, epidemiology, diagnosis, and treatment of AD, specifically highlighting commonly used therapies and novel medications. ( $\mathrm{J}$ Am Board Fam Med 2020;33:626-635.)

Keywords: Atopic Dermatitis, Chronic Disease, Dermatology, Eczema, Primary Health Care, Quality of Life, Skin Diseases

\section{Background}

Atopic dermatitis $(\mathrm{AD})$ is a common and chronic inflammatory skin disorder. ${ }^{1,2}$ In North America, the prevalence ranges between $9.8 \%$ and $10.3 \%$ in children ages 6 to 7 and $6.5 \%$ and $9.4 \%$ in ages 13 to $14 .^{3}$ Close to three-quarters of cases obtain complete remission by age $16 .{ }^{4}$ However, adult prevalence remains around $10 \% .^{5}$

This article was externally peer reviewed.

Submitted 12 December 2019; revised 2 March 2020; accepted 4 March 2020.

From Division of Dermatology, University of Toronto, Toronto, ON, Canada (PF, CL); MD Program, University of British Columbia, Vancouver, BC, Canada (YBY); Department of Family and Community Medicine, North York General Hospital, Toronto, ON, Canada (BO); Department of Family and Community Medicine, St. Michael's Hospital, Toronto, ON, Canada (KOL).

${ }^{\#}$ Co-first authors.

Funding: None.

Conflicts of Interest: PF has received honoraria and/or consulting fees and/or advisory board fees for AbbVie, Aralez, Altius, Cipher, Eli Lilly, Galderma, Janssen, Leo, Novartis, and Pfizer \& Sanofi. YBY has no conflicts of interest to declare. CL has acted as a principal investigator, speaker and/or consultant and/or advisory board fees for AbbVie, Amgen AnatpysBio, Avillon, Arcutis, Bristol-Myers Squibb, Celgene Cipher Genentech, GlenMark, Incyte, Janssen,
$\mathrm{AD}$ arises from an interplay between environmental exposures, epidermal barrier dysfunctions, and immune dysregulation. There is no single genetic cause of $\mathrm{AD}$; however, mutations in filaggrin seem to play an important role. ${ }^{6,7}$ Filaggrin deficiency weakens skin barrier integrity and increases epidermal permeability, thereby predisposing individuals with $\mathrm{AD}$ to irritant and allergic reactions. ${ }^{8-10}$ In children, FLG mutations positively correlate with development of atopies, such as rhinitis and asthma, ${ }^{7}$ which form the "atopic triad."

Leo Pharma, Kyowa, Pfizer, Merck Novartis, and Sanofi. BO has no conflicts of interest to declare. KOL has received honoraria and/or consulting fees and/or advisory board fees from Bausch, Eli Lilly \& Pfizer.

Corresponding author: Kyle O. Lee, BM, BS, CCFP, Sumac Creek Health Centre, St. Michael's Hospital, 73 Regent Park Blvd., 3rd floor, Toronto, Ontario M5A 2B7 (Email: Kyle.Lee@mail.utoronto.ca).

Biographical: PF is an Assistant Professor in the Division of Dermatology, University of Toronto. YBY is a senior medical student at the University of British Columbia. CL is an Associate Professor in the Division of Dermatology, University of Toronto. BO is an Assistant Professor in the Department of Family \& Community Medicine, University of Toronto, North York General Hospital. KOL is a Lecturer in the Department of Family \& Community Medicine, University of Toronto, St Michael's Hospital. 
Risk factors for $\mathrm{AD}$ include a family history of asthma (odds ratio [OR], 1.38; 95\% confidence interval [CI], 1.10-1.59), allergic rhinitis (OR, 1.33; 95\% CI, 1.14-1.54), or $\mathrm{AD}$ (OR, 2.4; 95\% CI, 1.89-3.05). ${ }^{11}$ Passive tobacco smoke seems to be associated with $\mathrm{AD} .{ }^{12}$ There is a higher prevalence of $\mathrm{AD}$ in urban than in rural environments. ${ }^{13} \mathrm{An}$ increased maternal intake of probiotics ${ }^{14,15}$ may have a modest benefit and prevent $\mathrm{AD}$.

\section{Clinical features}

$\mathrm{AD}$ is characterized by ill-defined, erythematous, and scaly plaques. The unaffected skin may have pruritus and xerosis. ${ }^{8,16}$ Acute lesions are characterized by erythematous papulovesicular papules and plaques, ${ }^{8,16}$ subacute lesions by poorly defined scaly erythematous patches, and chronic lesions as lichenified plaques. ${ }^{8,16} \mathrm{AD}$ can have different patterns in different age groups. Infant AD is characterized by head and neck and extensor limb surface involvement; the trunk may also be affected, but the diaper area is usually spared. ${ }^{8,16}$ Children present with a shift toward chronic lesions on the flexural folds around the wrists, ankles, hands, feet, and antecubital and popliteal fossae; there is a lower frequency of facial involvement in children than in infants. ${ }^{8,16}$ Adult $\mathrm{AD}$ usually affects the flexural areas and has a greater variety of subtypes, including those that exclusively affect the hands, nipples, genitalia, ${ }^{17}$ and/or eyelids. ${ }^{8,16}$

The most commonly used diagnostic criteria for $\mathrm{AD}$ include 4 components: (1) pruritus, (2) dermatitis in infant or adult distributions, (3) chronic or relapsing dermatitis, and (4) personal or family history of atopy. ${ }^{18}$ Twenty-three minor criteria, grouped into facial features, triggers, complications, and other (Table 1$)^{18}$ support an $\mathrm{AD}$ diagnosis. The presence of 3 major and 3 minor criteria are required for a definitive diagnosis of $\mathrm{AD} .{ }^{18,19}$

The severity of $\mathrm{AD}$ is commonly categorized $\mathrm{d}^{20,21}$ into mild-to-moderate $\mathrm{AD}$ involving limited areas of the body affected, milder intensity of pruritus, and sleep loss; and severe AD involving widespread areas of dry skin, high frequency of pruritus, and a significant impact on quality of life.

\section{Differential diagnosis}

The common differential for $\mathrm{AD}$ (Table 2) includes seborrheic dermatitis, irritant contact dermatitis, allergic contact dermatitis, plaque psoriasis, and scabies infestation. $^{20,23}$

Seborrheic dermatitis usually presents as illdefined erythema with greasy scale ${ }^{8}$ in areas with a high density of sebaceous glands, such as the nose, nasolabial folds, eyebrows, glabella, retro-auricular folds, and scalp. ${ }^{20}$ In infants, seborrheic dermatitis can cause cradle-cap: thick adherent greasy scale covering the scalp. ${ }^{22,24}$

Irritant contact dermatitis and allergic contact dermatitis can present similarly to $\mathrm{AD}$, with acute to chronic dermatitic lesions, but are usually confined to specific areas of exposure. ${ }^{8}$ Irritant contact dermatitis is a nonallergic irritation from direct exposure to solvents and often coexists with $\mathrm{AD} .^{7,20}$ Allergic contact dermatitis is a type IV hypersensitivity that occurs 12 to 72 hours after allergen exposure, and although it usually starts confined to the area of exposure, it is more likely to spread to surrounding areas than irritant contact dermatitis. ${ }^{8,20,23}$ Refractory cases of $\mathrm{AD}$ are commonly complicated by allergic contact dermatitis. Patch testing can be helpful to confirm the diagnosis of allergic contact dermatitis.

\section{Table 1. Diagnostic Criteria for Atopic Dermatitis ${ }^{18}$}

\begin{tabular}{|c|c|c|}
\hline Major Criteria $(3+)$ & & Minor Criteria $(3+)$ \\
\hline Pruritis & Facial features & $\begin{array}{l}\text { Facial pallor, erythema, hypopigmented patches, infraorbital } \\
\text { darkening, cheilitis, infraorbital folds (Dennie-Morgan lines), } \\
\text { recurrent conjunctivitis, anterior neck folds }\end{array}$ \\
\hline $\begin{array}{l}\text { Dermatitis affecting flexural surfaces in } \\
\text { adults or face and extensor surfaces } \\
\text { in infants }\end{array}$ & Triggers & Emotional factors, environmental factors, food, skin irritants \\
\hline Chronic or relapsing dermatitis & Complications & $\begin{array}{l}\text { Susceptibility to skin infections, impaired cell-mediated } \\
\text { immunity, predisposition to keratoconus and anterior } \\
\text { subcapsular cataracts, immediate skin reactivity }\end{array}$ \\
\hline $\begin{array}{l}\text { Personal or family history of cutaneous } \\
\text { or respiratory allergy }\end{array}$ & Other & $\begin{array}{l}\text { Early age of onset, xerosis, ichthyosis vulgaris, hyperlinear palms, } \\
\text { keratosis pilaris, hand or foot dermatitis, nipple dermatitis, } \\
\text { white dermatographism, perifollicular accentuation }\end{array}$ \\
\hline
\end{tabular}


Table 2. Common Conditions in the Differential Diagnosis of Atopic Dermatitis

\begin{tabular}{|c|c|c|c|}
\hline Condition & Morphology & Distribution & Pertinent Signs/Symptoms \\
\hline $\begin{array}{l}\text { Atopic } \\
\text { dermatitis }\end{array}$ & $\begin{array}{l}\text { Acute to chronic } \\
\text { dermatitic lesions }\end{array}$ & $\begin{array}{l}\text { Infant: face, head and neck, extensor } \\
\text { surfaces } \\
\text { Child: flexural folds with the wrist, } \\
\text { ankles, hands, feet, and } \\
\text { antecubital/popliteal fossae } \\
\text { Adult: flexural surface; many area- } \\
\text { specific subtypes }\end{array}$ & $\begin{array}{l}\text { Pruritus; personal or family } \\
\text { history of atopy }\end{array}$ \\
\hline $\begin{array}{l}\text { Irritant contact } \\
\text { dermatitis }\end{array}$ & $\begin{array}{l}\text { Acute to chronic } \\
\text { eczematous lesion }\end{array}$ & Confined to area of exposure & Burning/itch \\
\hline $\begin{array}{l}\text { Allergic contact } \\
\text { dermatitis }\end{array}$ & $\begin{array}{l}\text { Acute to chronic } \\
\text { eczematous lesion }\end{array}$ & $\begin{array}{l}\text { Initial confinement to area of } \\
\text { exposure but likely to spread }\end{array}$ & \\
\hline $\begin{array}{l}\text { Seborrheic } \\
\text { dermatitis }\end{array}$ & $\begin{array}{l}\text { Ill-defined areas of } \\
\text { erythema with } \\
\text { greasy scale }\end{array}$ & $\begin{array}{l}\text { Nose, nasolabial folds, eyebrows, } \\
\text { glabella, scalp } \\
\text { Children: cradle-cap and diaper } \\
\text { area often affected }\end{array}$ & $\begin{array}{l}\text { Children: self-resolving within } \\
2 \text { weeks }\end{array}$ \\
\hline Psoriasis & $\begin{array}{l}\text { Bright beefy-red, well- } \\
\text { circumscribed } \\
\text { plaques with silvery } \\
\text { micaceous scale }\end{array}$ & $\begin{array}{l}\text { Broad distribution with extensor } \\
\text { surface involvement } \\
\text { Children: diaper area often affected }\end{array}$ & $\begin{array}{l}\text { Nail changes (including pitting; } \\
\text { family history of psoriasis) }\end{array}$ \\
\hline Scabies & $\begin{array}{l}\text { Contiguous burrows of } \\
\text { serpiginous tracks } \\
\text { with secondary } \\
\text { eczematous changes }\end{array}$ & $\begin{array}{l}\text { Children: palms, soles, dorsal feet, } \\
\text { genitalia, diaper area } \\
\text { Adults: interdigital space, wrist, } \\
\text { axillae, waist, umbilicus, nipples, } \\
\text { genitals, breasts }\end{array}$ & $\begin{array}{l}\text { Severe pruritus, worse at night; } \\
\text { excoriated papules in } \\
\text { multiple areas }\end{array}$ \\
\hline
\end{tabular}

Plaque psoriasis usually presents as bright beefyred and well-circumscribed plaques with silvery "micaceous" scale in a symmetric distribution. It most often affects the scalp, nails, genitals, and extensor surfaces. ${ }^{23}$ Inverse psoriasis may also affect the flexural sites but will lack scale due to excessive moisture. $^{23}$

Scabies has a primary presentation of burrows of serpiginous tracks, which can cause a hypersensitivity and secondary dermatitis. ${ }^{25}$ It should be suspected in all patients with acute onset pruritus, and empiric treatment may be considered. In infants and children, the palms, soles, dorsal feet, genitalia, and diaper area are commonly affected; in adolescents and adults, the interdigital space, wrist, axillae, waist, umbilicus, and nipples are often involved. ${ }^{20,23}$

Rarely, malignancy such as cutaneous T-cell lymphomas can mimic dermatitis. It often affects the bathing trunk distribution and can be misdiagnosed as psoriasis or dermatitis, both clinically and on histopathology. 8,20

\section{Infectious Complications}

Due to impaired barrier function and decreased skin antimicrobial peptides, patients with $\mathrm{AD}$ are predisposed to bacterial and viral skin infections. The 2 most common secondary infections in AD management are impetigo and eczema herpeticum. ${ }^{8}$

Secondary infection of dermatitis is most often associated with Staphylococcus aureus or Streptococcus pyogenes. It may present with yellow crusting, pustules, and/or bulla. ${ }^{8} S$. aureus infections in $\mathrm{AD}$ are more likely methicillin resistant (MRSA) and produce superantigens, ${ }^{26}$ which can worsen dermatitis. Mild cases can be treated with topical antibiotics, such as $2 \%$ fusidic acid cream/ointment 2 or 3 times daily for 7 to 14 days, $2 \%$ mupirocin ointment 3 times daily for 10 days, or $1 \%$ ozenoxacin cream twice daily for 5 days. All 3 topical agents have activity against MRSA. Severe impetigo requires oral antibiotics, such as cephalexin. Cases of suspected MRSA should be treated with oral doxycycline or sulfamethoxazoletrimethoprim based on local resistance patterns.

Eczema herpeticum is a serious infection caused by latent herpes simplex virus. It presents as vesicles, punched-out erosions, hemorrhagic crusts, pain, lymphadenopathy, and/or fever. ${ }^{27}$ It can resemble and coexist with impetigo, making diagnosis challenging. Serious cases can involve keratoconjunctivitis and meningitis, leading to death. ${ }^{27}$ In suspected cases of eczema herpeticum, bacterial and viral microbiologic studies should be collected and patients should be treated empirically with systemic 
Figure 1. Treatment of AD. Abbreviations: TCS, Topical corticosteroids; AD, atopic dermatitis; PDE-4, Phosphodiesterase-4 inhibitor.

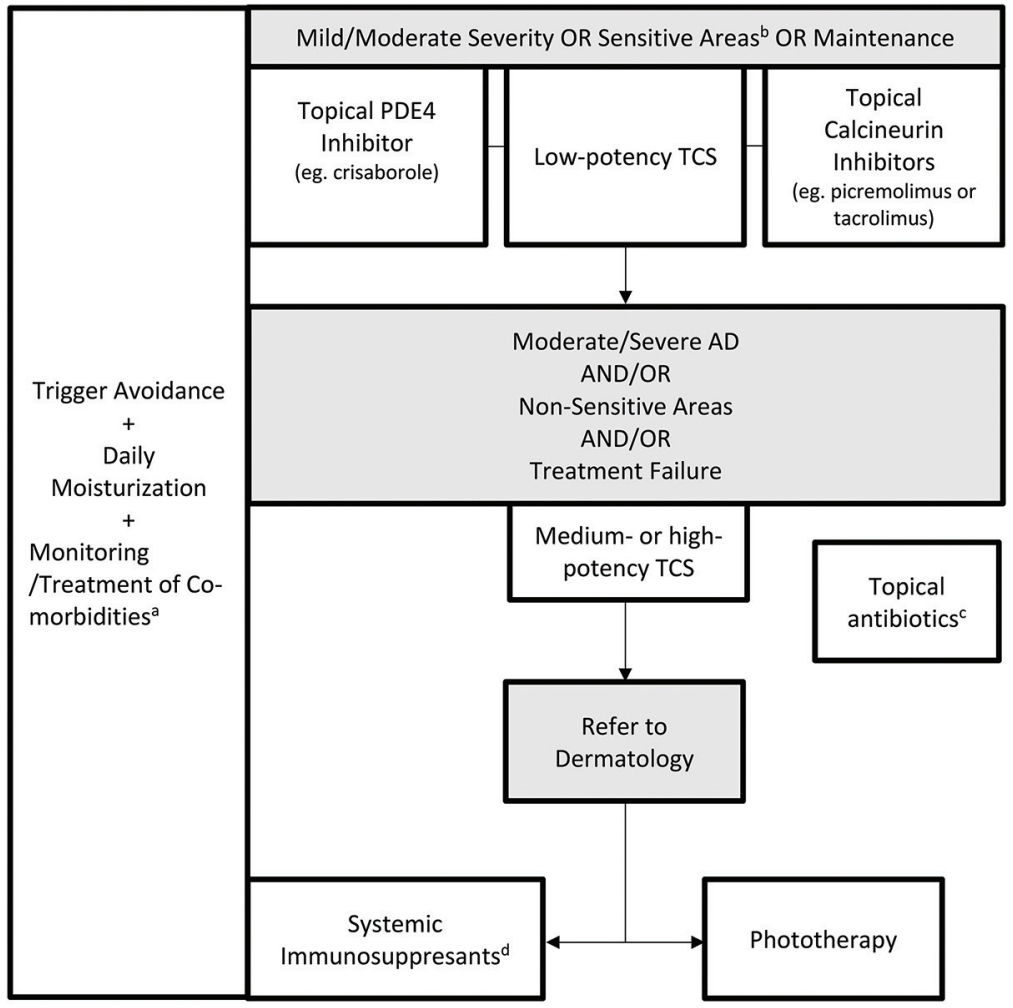

\footnotetext{
${ }^{a}$ Trigger avoidance, daily moisturization, and monitoring/treatment of co-morbidities should be done concurrently with all $\mathrm{AD}$ treatments.

${ }^{\mathrm{b}}$ Sensitive areas of the body include the face, skin folds, and groin.

${ }^{c}$ Topical anti-staphylococcal antibiotics may be used in combination with TCS when infection is superimposed on AD lesions.

${ }^{\mathrm{d}}$ Systemic immunosuppressants include methotrexate, mycophenolate mofetil, and dupilumab. Oral corticosteroids and/or cyclosporine may be used to control severe-moderate AD flares but should be limited to short-term use ${ }^{1}$.
}

antiviral medication. Patients should be referred urgently to dermatology and/or the emergency department.

\section{Comorbidities}

Patients with $\mathrm{AD}$ may have a higher prevalence of several comorbid medical and psychiatric conditions. The more widely known and prevalent conditions include allergic rhinitis, asthma, and food allergies ${ }^{28}$ particularly in the pediatric population. Obesity and cardiovascular conditions ${ }^{29}$ (such as myocardial infarction, unstable angina, early cardiovascular deaths, and others) have also been associated with more severe $\mathrm{AD}$, likely coinciding with other lifestyle factors, such as poor sleep, ${ }^{30}$ tobacco use, ${ }^{31,12}$ and decreased physical activity. ${ }^{32}$ Further studies are required to define appropriate and validated screening modalities in $\mathrm{AD}$ populations.

$\mathrm{AD}$ is associated with several mental health conditions. A US pediatric cross-sectional study ( $\mathrm{n}=92642$ ) reported a higher prevalence of depression (odds ratio [OR], 1.81; 95\% confidence interval [CI], 1.46-2.39), anxiety (OR, 1.77; 95\%, CI 1.36-2.29), conduct disorder (OR, 1.87; 95\% CI, 1.46-2.39), and autism (OR, 3.04; 95\% CI, 2.13-4.34) in AD patients. ${ }^{33}$ Meta-analyses have shown a higher prevalence of child and adult depression, ${ }^{34}$ as well as suicidal ideation ${ }^{35,36}(\mathrm{OR}$, 1.44; 95\% CI, 1.25-1.65) and attempted suicide (OR, 1.36; 95\% CI, 1.09-1.7). ${ }^{35,36}$ Reports of an association between $\mathrm{AD}$ and attention-deficit/hyperactivity disor$\operatorname{der}^{36}$ in the pediatric population have also been noted. There are also reports of independent sleep 
disturbances in children and their caregivers ${ }^{30,37}$ as well as adults. ${ }^{30}$

\section{Treatment}

\section{Moisturizers}

Regular use of moisturizers can both treat mild $\mathrm{AD}$ and prevent disease exacerbations ${ }^{8,38,39}$ and are the first-line and cornerstone of $\mathrm{AD}$ treatment (Figure 1). They are composed of various amounts of emollient and humectant and adjunct ingredients, such as ceramides, urea, lactate, and salicylic acid. These adjunct ingredients are physiologic lipids of the stratum corneum and act to hydrate and/or repair it, reducing pruritus, xerosis, flares, and infection. ${ }^{40}$ Ceramides comprise $50 \%$ of stratum corneum lip$\mathrm{ids}^{41}$ and are of particular interest in recent $\mathrm{AD}$ literature. A small study $(n=80)$ demonstrated that prophylactic use of ceramide-dominant emollients in infants at high risk for $\mathrm{AD}$ for 6 months starting in the neonatal period trended toward a reduced incidence of $\mathrm{AD}$ at 12 months. ${ }^{42}$ However, similar effects have also been noted in the use of standard emollients. ${ }^{43,44}$ Topical coconut oil has also been used in mild-to-moderate pediatric AD. ${ }^{45}$ Although many meta-analyses regarding the use of live oral probiotics have not shown consistent improvement in $\mathrm{AD}$ severity, ${ }^{46,47}$ some new moisturizers may include topical prebiotic ingredients. Regardless, no particular moisturizer or application regimen has shown superiority over others in direct comparisons for $\mathrm{AD}$ outcomes. $^{48,49}$ Moisturizers should be applied immediately after bathing or showering. ${ }^{42}$ Some studies have shown that $6 \%$ bleach baths can be used for their antimicrobial properties, ${ }^{50,51}$ but their benefit in $\mathrm{AD}$ has been controversial, with recent metaanalysis showing no difference with water baths. ${ }^{52}$

\section{Trigger Avoidance}

Some literature suggests that $\mathrm{AD}$ flares are seasonal and tend to correspond with periods of low humidity and low temperature. ${ }^{53}$ Patients with $\mathrm{AD}$ have a higher risk of irritant and allergic contact dermatitis, so common allergens such as fragranced products should be avoided. ${ }^{54,55}$ Clinicians should counsel patients on the importance of applying daily moisturizers to the entire body at least once per day and avoidance of common allergens and irritants. ${ }^{43}$

\section{Topical Corticosteroids and Antibiotics}

Topical corticosteroids (TCS) are the first-line medication $^{56}$ for controlling mild-to-moderate $\mathrm{AD}$
(Table 3). Proper use involves considering both the potency of TCS and lesion location. Mild potency corticosteroids should be used on the face and skin folds and moderate potency corticosteroids on the body. They are typically applied twice daily for 2 to 4 weeks. ${ }^{39}$ Acute flares and thick/lichenified lesions on the body can be treated with high potency TCS (I, II) for up to 2 weeks but should then be tapered to a lower potency until the lesion resolves. ${ }^{39}$

Adverse effects of TCS include cutaneous atrophy, especially on the face and skin folds. ${ }^{57}$ For these areas, low potency formulations (VI, VII) should be used ${ }^{56}$; however, if necessary, a 5- to 7day course of high potency steroid tapered to a lower dose is acceptable. ${ }^{16}$ As a guideline, roughly $0.5 \mathrm{~g}$ (1 adult fingertip) of topical steroid should be spread over 2 palms worth of $\operatorname{skin}^{16}$ and used 1 to 2 times daily, ${ }^{58}$ with liberal concurrent emollient application. ${ }^{8,16}$ If no effects are seen after 2 weeks, clinicians should consider alternative potencies or medications or consider another diagnosis. ${ }^{16}$ Due to widespread concern regarding steroid atrophy among patients and health providers, many patients underapply TCS, which can lead to decreased efficacy and inadequate symptom control. ${ }^{55}$ Patients should be counseled on adequate application for the amount and duration of medication use. Prophylactic use of low-to-moderate potency TCS can be used to control continually refractory lesions. ${ }^{38}$ Further side effects of TCS, including telangiectasia, striae, acneiform or rosacea-like eruptions, allergic contact dermatitis, and impairment of wound healing, are uncommon with appropriate use and can be effectively mananged. ${ }^{59}$

Topical antibiotics, such as fusidic acid and mupirocin, are recommended as an adjunct medication with topical anti-inflammatories when signs of infection, such as crusting, oozing, and pus, coexist with $\mathrm{AD} \cdot{ }^{60}$ Ozenoxacin cream $(1 \%)$ is a novel topical antibiotic with activity against MRSA that was recently approved for treating impetigo in patients ages 2 months and over and is applied twice daily for 5 days. ${ }^{61}$ Corticosteroid and antibiotic combination creams, such as $0.1 \%$ fusidic acid/betamethasone valerate or $1 \%$ fusidic acid/hydrocortisone exist, but the prophylactic use of topical antibiotics on $\mathrm{AD}$ lesions without signs of infection is not recommended. ${ }^{38}$ Swabs for culture and sensitivity should also be considered due to the rising incidence of resistant organisms. ${ }^{38}$ At present, antistaphylococcal topical antibiotics show noninferiority 
Table 3. Prescription Therapies for Atopic Dermatitis

\begin{tabular}{|c|c|c|c|c|}
\hline Therapy & Indication & $\begin{array}{l}\text { Dosage and } \\
\text { Scheduling }\end{array}$ & Side Effect & Pearls \\
\hline $\begin{array}{l}\text { Topical corticosteroids } \\
\text { (TCS) } \pm \\
\text { Antistaphylococcal } \\
\text { antibiotics* (fucidic } \\
\text { acid, mupirocin, } \\
\text { bacitracin/ } \\
\text { polymyxin B, } \\
\text { ozenoxacin } 1 \%)\end{array}$ & $\begin{array}{l}\text { First-line prescription } \\
\text { therapy if } \\
\text { uncontrolled by } \\
\text { moisturizers/irritant } \\
\text { avoidance }\end{array}$ & $\begin{array}{l}\text { Mild lesions: moderate } \\
\text { potency for } 2 \text { to } 4 \\
\text { weeks } \\
\text { Acute flares: high } \\
\text { potency for up to } \\
2 \text { weeks } \\
\text { Apply } 1 \times \text { to } 2 \times \text { daily }\end{array}$ & $\begin{array}{l}\text { Steroid atrophy, purpura, } \\
\text { telangiectasia, striae, } \\
\text { focal hypertrichosis, } \\
\text { acneiform or rosacea- } \\
\text { like eruptions, allergic } \\
\text { contact dermatitis, } \\
\text { impairment of wound } \\
\text { healing }\end{array}$ & $\begin{array}{l}\text { High potency TCS for } \\
\text { areas of high } \\
\text { absorption } \\
\text { acceptable for } 5 \text { to } \\
7 \text { days before } \\
\text { tapering }\end{array}$ \\
\hline $\begin{array}{l}\text { Topical calcineurin } \\
\text { inhibitors (TCIs) }\end{array}$ & $\begin{array}{l}\text { Second-line treatment of } \\
\text { mild-to-moderate } \\
\text { atopic dermatitis in } \\
\text { patients aged } 2 \text { years } \\
\text { and above (aged } \\
3 \text { months and above } \\
\text { for pimecrolimus) }\end{array}$ & On-label dosing & $\begin{array}{l}\text { Potential black box } \\
\text { warning, temporary } \\
\text { application-site } \\
\text { burning }\end{array}$ & $\begin{array}{l}\text { Avoid use on } \\
\text { suspected eczema } \\
\text { herpeticum; } \\
\text { tacrolimus is also } \\
\text { indicated for } \\
\text { maintenance } \\
\text { treatment to prevent } \\
\text { flares }\end{array}$ \\
\hline $\begin{array}{l}\text { Topical PDE-4 } \\
\text { inhibitors }\end{array}$ & $\begin{array}{l}\text { First-line treatment of } \\
\text { mild-to-moderate } \\
\text { atopic dermatitis in } \\
\text { patients aged } 2 \text { years } \\
\text { and above }\end{array}$ & On-label dosing & $\begin{array}{l}\text { Transient application- } \\
\text { site burning }\end{array}$ & \\
\hline \multicolumn{5}{|c|}{ Treatment for Severe Atopic Dermatitis } \\
\hline Phototherapy & $\begin{array}{l}\text { Failure of topical } \\
\text { treatments }\end{array}$ & $\begin{array}{l}2 \times \text { to } 5 \times \text { weekly } \\
\text { administration }\end{array}$ & $\begin{array}{l}\text { Erythema, sunburn, } \\
\text { advanced skin-aging, } \\
\text { itching, nausea }\end{array}$ & $\begin{array}{l}\text { Burdensome and } \\
\text { expensive }\end{array}$ \\
\hline $\begin{array}{l}\text { Systemic } \\
\text { immunosuppressants } \\
\text { (eg, methotrexate } \\
\text { [MTX], } \\
\text { microphenylate } \\
\text { mofetil [MMF], and } \\
\text { azathioprine [AZA]) }\end{array}$ & $\begin{array}{l}\text { Failure of topical } \\
\text { treatments }\end{array}$ & $\begin{array}{l}\text { MTX: } 15 \mathrm{mg} / \text { week } \\
\text { (adults) } \\
\text { MMF: } 0.5 \text { to } 3 \mathrm{~g} / \text { day } \\
\text { (adult) or } 40 \text { to } 50 \\
\text { mg/ } / \mathrm{kg} / \mathrm{day} \\
\text { (pediatric) } \\
\text { AZA: } 1 \text { to } 3 \mathrm{mg} / \mathrm{kg} / \\
\text { day (adult) }\end{array}$ & $\begin{array}{l}\text { Gastrointestinal upset, } \\
\text { nausea, vomiting, } \\
\text { fatigue, hepatotoxicity, } \\
\text { bone marrow } \\
\text { suppression, idiopathic } \\
\text { pulmonary fibrosis, } \\
\text { teratogenicity, } \\
\text { headache, leukopenia, } \\
\text { hypersensitivity, } \\
\text { bloating, anorexia }\end{array}$ & $\begin{array}{l}\text { Order tuberculosis } \\
\text { test, chest } \\
\text { radiograph, hepatitis } \\
\text { serologies, and } \\
\text { ensure } \\
\text { immunizations are } \\
\text { up to date }\end{array}$ \\
\hline Dupilumab & $\begin{array}{l}\text { Failure of topical } \\
\text { treatments }\end{array}$ & $\begin{array}{l}600 \mathrm{mg} \text { subcutaneous } \\
\text { loading dose } \\
\text { followed by } 300 \mathrm{mg} \\
\text { subcutaneous dose } \\
\text { every } 2 \text { weeks }\end{array}$ & $\begin{array}{l}\text { Hypersensitivity } \\
\text { reactions, anaphylaxis, } \\
\text { injection site reactions, } \\
\text { conjunctivitis }\end{array}$ & $\begin{array}{l}\text { High cost, no baseline } \\
\text { investigations or } \\
\text { routine laboratory } \\
\text { monitoring required }\end{array}$ \\
\hline
\end{tabular}

*Topical antistaphylococcal antibiotics should be used as an adjunct to TCS treatment in the presence of signs of mild infection concurrent with atopic dermatitis. Combination topical steroid and antibiotic creams exist.

Tcs, topical corticosteroids; Tci, topical calcineurin inhibitors; PDE-4, Phosphodiesterase-4 inhibitor; mtx, methotrexate; mmf, microphenylate mofetil; aza, azathioprine.

to 1 another for the treatment response of infected AD lesions. ${ }^{61}$

\section{Topical Calcineurin Inbibitors}

Topical calcineurin inhibitors (TCIs) are nonsteroidal agents that inhibit calcineurin-dependent $\mathrm{T}$ cell activation. ${ }^{16}$ TCIs may be used as an alternative treatment or for prolonged treatment when steroid atrophy is a concern. ${ }^{38}$ They may also be used as adjunctive or maintenance therapy alongside high- dose TCS. $^{16}$ Two TCIs are used in practice: $1 \%$ pimecrolimus and $0.03 \%$ or $0.1 \%$ tacrolimus, with both showing efficacy in short-term (3 to 12 week) and long-term (up to 12 months) use in adult and pediatric populations. Pimecrolimus (1\%) is less effective than TCS but has value as a long-term maintenance therapy, and $0.1 \%$ tacrolimus is noninferior to moderately potent TCS. ${ }^{62}$ TCIs also may be used for the prophylactic treatment of recurrent flares, applied 2 to 3 times per week to 
prevent relapse. ${ }^{16}$ The most common side effect of TCIs ${ }^{16,62}$ is a burning or stinging sensation over the applied area; however, this often decreases with continual use. ${ }^{16}$ They should be discontinued if allergic/contact dermatitis or rosacea-like lesions develop. ${ }^{16}$ The US FDA has a black box warning concerning the long-term safety of TCIs due to an association of systemic immunosuppression with skin malignancies and lymphoma ${ }^{63}$; however, follow-up studies have failed to verify this. ${ }^{64,65}$ Currently, the Canadian Dermatology Association does not support this black box warning ${ }^{66}$ and has recently been removed from the product monograph of pimecrolimus. ${ }^{67}$

\section{Topical PDE-4 Inbibitors}

Crisaborole (2\%) ointment is a topical PDE-4 inhibitor that was approved for $\mathrm{AD}$ treatment by Health Canada in 2018 for patients older than 2 years. ${ }^{67}$ It has shown benefit in controlling the signs and symptoms of $\mathrm{AD}$ in acute and chronic lesions for both adult and pediatric populations and is welltolerated in areas susceptible to steroid atrophy, such as the face, skin folds, and groin. ${ }^{68}$ Current safety profiles of up to 52 weeks ${ }^{69}$ show that crisaborole has a reduced risk of systemic side effects compared with TCS and TCIs. ${ }^{70}$ The most common side effect noted in clinical trials has been temporary application site burning (4.4\% crisaborole vs $1.2 \%$ control; $P=.001$ ) but typically resolves after the first day of application. ${ }^{68,70}$

\section{Phototherapy}

Phototherapy is a treatment option in $\mathrm{AD}$ for those in which topical treatments do not achieve adequate control. ${ }^{71}$ It typically involves a 2 to 5 times weekly administration of narrowband (309 to $312 \mathrm{~nm}$ ) $\mathrm{UVB}^{72}$ to affected areas and shows benefit in the signs, symptoms, and quality of life in $\mathrm{AD}$ patients. ${ }^{73-78}$ Side effects of phototherapy range from erythema, advanced skin-aging, burning, itching, and nausea. ${ }^{16,78}$ Although it is effective, phototherapy access remains an issue for many patients and the frequency of treatments can be burdensome.

\section{Dupilumab and JAK Inbibitors}

Dupilumab is a subcutaneously administered human monoclonal antibody for the interleukin-4 receptor- $\alpha$ subunit and is approved for the treatment of moderate-severe $\mathrm{AD}$ in North America and Europe. ${ }^{79}$ A meta-analysis of $8 \mathrm{AD}$ trials with dupilumab showed a relative risk of skin infection of 0.54 (95\% CI, 0.42-0.70) and OD of eczema herpeticum of 0.34 (95\% CI, 0.14-0.84) in dupilumab versus placebo, with no significant associations with herpes simplex virus or overall skin infections. ${ }^{80}$ Patients receiving dupilumab may also be at an increased risk of conjunctivitis. ${ }^{81} \mathrm{No}$ baseline or follow-up laboratory monitoring is required. Ongoing studies are assessing longer-term effects. ${ }^{82}$

A new class of emerging $\mathrm{AD}$ therapy are JAK inhibitors, which act on a common inflammatory pathway of many dermatoses, including $\mathrm{AD}$, alopecia areata, psoriasis, and vitiligo. ${ }^{83}$ Currently, phase II and III studies are ongoing for topical and oral formulations.

\section{Conclusions}

The management of $\mathrm{AD}$ should involve the liberal use of emollients and an avoidance of common irritants. In mild-to-moderate AD, TCS are the firstline medical therapy, followed by calcineurin inhibitors, which have been shown to be noninferior to TCS in controlling AD, without the risk of steroid atrophy. Topical PDE-4 inhibitors, such as crisaborole, are a new nonsteroidal anti-inflammatory approved for ages 2 years and older. For cases of $\mathrm{AD}$ that fail to be controlled with topical therapy, phototherapy should be considered, if available. Newer biologics, such as dupilumab, have been approved for moderate-to-severe $\mathrm{AD}$ and seem to have favorable efficacy and side-effect profiles according to randomized trials.

To see this article online, please go to: http://jabfm.org/content/ 33/4/626.full.

\section{References}

1. Drucker A, Eyerich K, de Bruin-Weller M, et al. Use of systemic corticosteroids for atopic dermatitis: International Eczema Council consensus statement. Br J Dermatol 2018;178:768-75.

2. Barbarot S, Auziere S, Gadkari A, et al. Epidemiology of atopic dermatitis in adults: Results from an international survey. Allergy 2018;73: 1284-1293.

3. Mallol J, Crane J, von Mutius E, et al. The International Study of Asthma and Allergies in Childhood (ISAAC) phase three: a global synthesis. Allergol Immunopathol (Madr) 2013;41:73-85.

4. Williams H, Strachan D. The natural history of childhood eczema: observations from the British 
1958 birth cohort study. Br J Dermatol 1998;139: 834-9.

5. Silverberg JI, Hanifin JM. Adult eczema prevalence and associations with asthma and other health and demographic factors: a US population-based study. J Allergy Clin Immunol 2013;132:1132-8.

6. Paternoster L, Standl M, Waage J, et al. Multi-ancestry genome-wide association study of 21,000 cases and 95,000 controls identifies new risk loci for atopic dermatitis. Nat Genet 2015;47:1449-56.

7. Rodríguez E, Baurecht $\mathrm{H}$, Herberich E, et al. Meta-analysis of filaggrin polymorphisms in eczema and asthma: robust risk factors in atopic disease. J Allergy Clin Immunol 2009;123:1361-70.e7.

8. Weidinger S, Novak N. Atopic dermatitis. Lancet 2016;387:1109-22.

9. Tsakok T, Woolf R, Smith C, Weidinger S, Flohr C. Atopic dermatitis: the skin barrier and beyond. Br J Dermatol 2019;180:464-74.

10. Kim J, Kim BE, Leung DY. Pathophysiology of atopic dermatitis: clinical implications. Allergy asthma Proc 2019;40:84-92.

11. Draaisma E, Garcia-Marcos L, Mallol J, et al. A multinational study to compare prevalence of atopic dermatitis in the first year of life. Pediatr Allergy Immunol 2015;26:359-66.

12. Kantor R, Kim A, Thyssen JP, Silverberg JI. Association of atopic dermatitis with smoking: a systematic review and meta-analysis. J Am Acad Dermatol 2016;75:1119-25.e1.

13. Schram M, Tedja A, Spijker R, Bos J, Williams H, Spuls PI. Is there a rural/urban gradient in the prevalence of eczema? A systematic review. $\mathrm{Br} \mathrm{J}$ Dermatol 2010;162:964-73.

14. Lee J, Seto D, Bielory L. Meta-analysis of clinical trials of probiotics for prevention and treatment of pediatric atopic dermatitis. J Allergy Clin Immunol 2008;121:116-21.e11.

15. Pelucchi C, Chatenoud L, Turati F, et al. Probiotics supplementation during pregnancy or infancy for the prevention of atopic dermatitis: a meta-analysis. Epidemiology 2012;23:402-14.

16. Fortson E, Feldman S, Strowd L. Management of atopic dermatitis: methods and challenges: New York (NY): Springer; 2017.

17. Silverberg JI, Margolis DJ, Boguniewicz M, et al. Distribution of atopic dermatitis lesions in United States adults. J Eur Acad Dermatol Venereol 2019;33:1341-8.

18. Hanifin J, Rajka G. Diagnostic features of atopic dermatitis. Dermatol Venereol 1980;92:44-7.

19. Rothe M, Grant-Kels J. Diagnostic criteria for atopic dermatitis. Lancet 1996;348:769-70.

20. Weston $W$, Howe $W$. Overview of dermatitis (Eczema). UpToDate. Available from: https://www. uptodate.com/contents/overview-of-dermatitiseczema. Published 2018.
21. Severity scoring of atopic dermatitis: the SCORAD Index (consensus report of the European Task Force on Atopic Dermatitis). Dermatology 1993; 186:23-31.

22. National Institute for Health and Clinical Excellence. Atopic eczema in under 12s: diagnosis and management. London: NICE; 2007. Available from: www.nice.org.uk/CG057.

23. Barrett M, Luu M. Differential diagnosis of atopic dermatitis. Immunol Allergy Clin North Am 2017;37:11-34.

24. Gupta A, Bluhm R. Seborrheic dermatitis. J Eur Acad Dermatol Venerol 2004;18:13-26.

25. Johnston G, Sladden M. Scabies: diagnosis and treatment. BMJ 2005;331:619-22.

26. Schlievert PM, Strandberg KL, Lin Y-C, Peterson ML, Leung DY. Secreted virulence factor comparison between methicillin-resistant and methicillinsensitive Staphylococcus aureus, and its relevance to atopic dermatitis. J Allergy Clin Immunol 2010; 125:39-49.

27. Sun D, Ong PY. Infectious complications in atopic dermatitis. Immunol Allergy Clin North Am 2017;37:75-93.

28. Silverberg JI. Comorbidities and the impact of atopic dermatitis. Ann Allergy Asthma Immunol 2019;123:144-51.

29. Ascott A, Mulick A, Yu AM, et al. Atopic eczema and major cardiovascular outcomes: a systematic review and meta-analysis of population-based studies. J Allergy Clin Immunol 2019;143:1821-9.

30. Jeon C, Yan D, Nakamura M, et al. Frequency and management of sleep disturbance in adults with atopic dermatitis: a systematic review. Dermatol Ther (Heidelb) 2017;7:349-64.

31. Lee CH, Chuang HY, Hong CH, et al. Lifetime exposure to cigarette smoking and the development of adult-onset atopic dermatitis. $\mathrm{Br} \mathrm{J}$ Dermatol 2011;164:483-489.

32. Silverberg JI, Song J, Pinto D, et al. Atopic dermatitis is associated with less physical activity in US adults. J Invest Dermatol 2016;136:1714-6.

33. Yaghmaie P, Koudelka CW, Simpson EL. Mental health comorbidity in patients with atopic dermatitis. J Allergy Clin Immunol 2013;131: 428-33.

34. Patel KR, Immaneni S, Singam V, Rastogi S, Silverberg JI. Association between atopic dermatitis, depression, and suicidal ideation: a systematic review and meta-analysis. J Am Acad Dermatol 2019;80:402-10.

35. Sandhu JK, Wu KK, Bui T-L, Armstrong AW. Association between atopic dermatitis and suicidality: a systematic review and meta-analysis. JAMA Dermatol 2019;155:178-87.

36. Schmitt J, Romanos M, Schmitt NM, Meurer M, Kirch W. Atopic eczema and attention-deficit/ 
hyperactivity disorder in a population-based sample of children and adolescents. JAMA 2009;301: 724-6.

37. Chamlin SL, Mattson CL, Frieden IJ, et al. The price of pruritus: sleep disturbance and cosleeping in atopic dermatitis. Arch Pediatr Adolesc Med 2005;159:745-50.

38. Weinstein M, Barber K, Bergman J, et al. Atopic dermatitis: a practical guide to management. Health Care Provid Resour 2016;12:1-12.

39. Dhadwal G, Albrecht L, Gniadecki R, et al. Approach to the assessment and management of adult patients with atopic dermatitis: a consensus document. section IV: treatment options for the management of atopic dermatitis. J Cutan Med and Surg 2018;22:21S-29S.

40. Draelos ZD. The science behind skin care: moisturizers. J Cosmet Dermatol 2018;17:138-44.

41. Feingold KR. Thematic review series: skin lipids. The role of epidermal lipids in cutaneous permeability barrier homeostasis. J Lipid Res 2007;48: 2531-46.

42. Lowe A, Su J, Allen K, et al. A randomized trial of a barrier lipid replacement strategy for the prevention of atopic dermatitis and allergic sensitization: the PEBBLES pilot study. Br J Dermatol 2018;178: e19-e21.

43. Horimukai K, Morita K, Narita M, et al. Application of moisturizer to neonates prevents development of atopic dermatitis. J Allergy Clin Immunol 2014;134:824-30.e6.

44. Simpson EL, Chalmers JR, Hanifin JM, et al. Emollient enhancement of the skin barrier from birth offers effective atopic dermatitis prevention. J Allergy Clin Immunol 2014;134:818-23.

45. Evangelista MT, Abad-Casintahan F, LopezVillafuerte L. The effect of topical virgin coconut oil on SCORAD index, transepidermal water loss, and skin capacitance in mild to moderate pediatric atopic dermatitis: a randomized, double-blind, clinical trial. Int J Dermatol 2014;53:100-8.

46. Moro G, Arslanoglu S, Stahl B, et al. A mixture of prebiotic oligosaccharides reduces the incidence of atopic dermatitis during the first six months of age. Arch Dis Child 2006;91:814-9.

47. Grüber C, Van Stuijvenberg M, Mosca F, et al. Reduced occurrence of early atopic dermatitis because of immunoactive prebiotics among low-atopy-risk infants. J Allergy Clin Immunol 2010;126:791-7.

48. Hon KL, Kung JSC, Ng WGG, et al. Emollient treatment of atopic dermatitis: latest evidence and clinical considerations. Drugs Context 2018;7: 212530.

49. Hon KL, Leung AK, Barankin B. Barrier repair therapy in atopic dermatitis: an overview. Am J Clin Dermatol 2013;14:389-99.

50. Wong S-M, Ng TG, Baba R. Efficacy and safety of sodium hypochlorite (bleach) baths in patients with moderate to severe atopic dermatitis in Malaysia. J Dermatol 2013;40:874-80.

51. Huang JT, Rademaker A, Paller AS. Dilute bleach baths for Staphylococcus aureus colonization in atopic dermatitis to decrease disease severity. Arch Dermatol 2011;147:246-7.

52. Chopra R, Vakharia PP, Sacotte R, Silverberg JI. Efficacy of bleach baths in reducing severity of atopic dermatitis: a systematic review and metaanalysis. Ann Allergy Asthma Immunol 2017;119: 435-40.

53. Engebretsen K, Johansen J, Kezic S, Linneberg A, Thyssen J. The effect of environmental humidity and temperature on skin barrier function and dermatitis. J Eur Acad Dermatol Venereol 2016;30:223-49.

54. Scheinman PL. Allergic contact dermatitis to fragrance: a review. Am J Contact Dermatitis 1996;7: 65-76.

55. Larsen $W$, Nakayama $H$, Lindberg $M$. Fragrance contact dermatitis: a worldwide multicenter investigation (part I). Am J Contact Dermat 1996;7:77-83.

56. Hoare C, Li Wan Po A, Williams H. Systematic review of treatments for atopic eczema. Health Technol Assess 2000;4:1.

57. Mayba JN, Gooderham MJ. Review of atopic dermatitis and topical therapies. J Cutan Med Surg 2017;21:227-36.

58. Green C, Colquitt J, Kirby J, Davidson P, Payne E. Clinical and cost-effectiveness of once-daily versus more frequent use of same potency topical corticosteroids for atopic eczema: a systematic review and economic evaluation. Health Technol Assess 2004;8:1-120.

59. Bewley A, Dermatology Working Group. Expert consensus: time for a change in the way we advise our patients to use topical corticosteroids. $\mathrm{Br} \mathrm{J}$ Dermatol 2008;158:917-20.

60. Rosen T, Albareda N, Rosenberg N, et al. Efficacy and safety of ozenoxacin cream for treatment of adult and pediatric patients with impetigo: a randomized clinical trial. JAMA Dermatol 2018; 154:806-13.

61. Cowling T, Jones S. Topical antibiotics for infected wounds: a review of the clinical effectiveness and guidelines. Ottawa (ON): Canadian Agency for Drugs and Technologies in Health; 2017.

62. El-Batawy MMY, Bosseila M-W, Mashaly HM, Hafez V. Topical calcineurin inhibitors in atopic dermatitis: a systematic review and meta-analysis. J Dermatol Sci 2009;54:76-87.

63. Legendre L, Barnetche T, Mazereeuw-Hautier J, Meyer N, Murrell D, Paul C. Risk of lymphoma in patients with atopic dermatitis and the role of topical treatment: A systematic review and meta-analysis. J Am Acad Dermatol 2015;72:992-1002.

64. Bausch Health Canada. Elidel (pimecrolimus) product monograph. Available from: https://pdf.hres.ca/ 
dpd_pm/00053301.PDF. Published November 3, 2011. Accessed March 2, 2020.

65. Cury Martins J, Martins C, Aoki V, Gois A, Ishii H, da Silva E. Topical tacrolimus for atopic dermatitis. Cochrane Database Syst Rev 2015;2015: CD009864.

66. Canadian Dermatology Association. Topical calcineurin inhibitors position statement. Available from: https://www.dermatology.ca/tciposition-statement/. Published 2018.

67. Zebda R, Paller AS. Phosphodiesterase 4 inhibitors. J Am Acad Dermatol 2018;78:S43-S52.

68. Hoy SM. Crisaborole ointment 2\%: a review in mild to moderate atopic dermatitis. Am J Clin Dermatol 2017;18:837-43.

69. Eichenfield LF, Call RS, Forsha DW, et al. Longterm safety of crisaborole ointment $2 \%$ in children and adults with mild to moderate atopic dermatitis. J Am Acad Dermatol 2017;77:641-9.e5.

70. Paller AS, Tom WL, Lebwohl MG, et al. Efficacy and safety of crisaborole ointment, a novel, nonsteroidal phosphodiesterase 4 (PDE4) inhibitor for the topical treatment of atopic dermatitis (AD) in children and adults. J Am Acad Dermatol 2016;75:494503.e496.

71. Sidbury R, Davis DM, Cohen DE, et al. Guidelines of care for the management of atopic dermatitis: section 3. Management and treatment with phototherapy and systemic agents. J Am Acad Dermatol 2014;71:327-49.

72. Jekler J, Larkö O. UVB phototherapy of atopic dermatitis. Br J Dermatol 1988;119:697-705.

73. Jekler J, Larkö O. Combined UVA-UVB versus UVB phototherapy for atopic dermatitis: a paired-comparison study. J Am Acad Dermatol 1990;22:49-53.

74. Meduri NB, Vandergriff T, Rasmussen H, Jacobe H. Phototherapy in the management of atopic dermatitis: a systematic review. Photoderm Photoimm Photomed 2007;23:106-12.

75. Tzaneva S, Seeber A, Schwaiger M, Hönigsmann $\mathrm{H}$, Tanew A. High-dose versus medium-dose UVA1 phototherapy for patients with severe generalized atopic dermatitis. J Am Acad Dermatol 2001;45:503-7.

76. Abeck D, Schmidt T, Fesq H, et al. Long-term efficacy of medium-dose UVA1 phototherapy in atopic dermatitis. J Am Acad Dermatol 2000;42:254-7.

77. Grundmann-Kollmann M, Behrens S, Podda M, Peter RU, Kaufmann R, Kerscher M. Phototherapy for atopic eczema with narrow-band UVB. J Am Acad Dermatol 1999;40:995-7.

78. Sidbury R, Tom WL, Bergman JN, et al. Guidelines of care for the management of atopic dermatitis: Section 4. Prevention of disease flares and use of adjunctive therapies and approaches. J Am Acad Dermatol 2014;71:1218-33.

79. Gooderham MJ, Hong H-h, Eshtiaghi P, Papp KA. Dupilumab: a review of its use in the treatment of atopic dermatitis. J Am Acad Dermatol 2018;78: S28-S36.

80. Fleming $\mathrm{P}$, Drucker AM. Risk of infection in patients with atopic dermatitis treated with dupilumab: a meta-analysis of randomized controlled trials. J Am Acad Dermatol 2018;78:62-9. e61.

81. Agnihotri G, Shi K, Lio PA. A clinician's guide to the recognition and management of dupilumab-associated conjunctivitis. Drugs R D 2019;19:311-8.

82. Worm M, Simpson EL, Thaçi D, et al. Efficacy and safety of multiple dupilumab dose regimens after initial successful treatment in patients with atopic dermatitis: a randomized clinical trial. JAMA Dermatol 2020;156:131-143.

83. Damsky $W$, King BA. JAK inhibitors in dermatology: the promise of a new drug class. J Am Acad Dermatol 2017;76:736-44. 